\title{
POR QUE O CONDOMÍNIO EDILÍCIO NÃO PODE SER PESSOA JURÍDICA? FRAGILIDADES DAS CONCEPÇÕES USUAIS DA DOUTRINA BRASILEIRA
}

\section{WHY DOES THE BUILDING CONDOMINIUM CANNOT BE A LEGAL PERSON? WEAKNESSES OF THE USUAL CONCEPTIONS OF BRAZILIAN DOCTRINE}

\begin{abstract}
ANNA CLARA LEHMANN MARTINS
Estudante do Curso de Graduação em Direito da Universidade Federal de Santa Maria (UFSM). Integrante do Núcleo de Direito Informacional (NUDI) - UFSM. Membro da equipe do blog do NUDI: http://www.ufsm.br/nudi.

laclaramartins@gmail.com
\end{abstract}

\begin{abstract}
RESUMO
Este artigo busca apontar as fragilidades das concepções usuais da doutrina jurídica brasileira ao não reconhecer o condomínio edilício como pessoa jurídica, tendo em vista os problemas que esse posicionamento traz para o âmbito prático. 0 método de abordagem utilizado é o crítico-reflexivo, e a técnica de execução de pesquisa é a documental. Os resultados mostram que a doutrina brasileira adota uma concepção unívoca do condomínio, limitando-se a abordá-lo em sua acepção objetiva - como direito real -, em detrimento de sua acepção subjetiva - como coletividade de condôminos. Dada a relevância da última para uma possível personificação do condomínio, percebe-se que o entendimento usual não é isento de brechas ou possibilidades de relativização.
\end{abstract}

Palavras-chave: condomínio edilício; direitos reais; pessoa jurídica.

\begin{abstract}
This paper seeks to identify the weaknesses of the usual conceptions of Brazilian legal doctrine concerning the non-recognition of the building condominium as a legal person, having in mind the problems that such position brings to the practical sphere. The method of approach used is the critical and reflexive one, and the technique of execution is the documental one. Results show that Brazilian doctrine adopts an univocal concept of building condominium, limited to the objective sense condominium as a real right -, in disregard of its subjective meaning - condominium as a collectivity of shareholders. Given the importance of the latter to a possible personification of the building condominium, it is perceived that the current understanding has its gaps and it is capable of relativization.
\end{abstract}

Keywords: building condominium; legal person; real rights.

\section{SUMÁRIO}

INTRODUÇAO; 1 CONSTRUÇÕES TEÓRICAS INICIAIS; 1.1 Pessoa jurídica - conceito, requisitos e características; 1.2 Condomínio edilício - conceito e apontamentos iniciais sobre sua não consideração como pessoa jurídica no ordenamento brasileiro; 2 FRAGILIDADES DAS CONCEPÇÕES DE NÃO CONSIDERAÇÃO DO CONDOMÍNIO EDILÍCIO COMO PESSOA JURÍDICA; 2.1 Condomínio edilício como ente despersonalizado; 2.2 Condomínio como expediente técnico a indicar a coletividade de condôminos; CONSIDERAÇÕES FINAIS; REFERÊNCIAS. 


\section{INTRODUÇÃO}

É dominante na doutrina brasileira a concepção de que o instituto do condomínio edilício não pode ser considerado pessoa jurídica. Argumenta-se que faltam elementos ao condomínio para essa subsunção, restando a ele ser classificado como ente de personalidade incompleta ou ausente. As designações para tal são várias: “ente despersonalizado”, “entidade anômala”, “mero expediente técnico”. Ainda assim, há vozes dissidentes, defensoras da personificação do condomínio edilício, tendo em vista que esse reconhecimento solucionaria boa parte dos entraves que a despersonalização traz para a administração do condomínio e os interesses dos condôminos. Tais vozes doutrinárias e legislativas (!) levam a que seja questionado: por que o condomínio edilício não pode ser pessoa jurídica? Quais são os argumentos que apoiam esse status quo? E finalmente: quais as fragilidades desses argumentos - a permitir que a doutrina dissidente subsista?

Com essa situação problema em mente, o objetivo do presente trabalho é, uma vez elaborados conceitos sólidos de pessoa jurídica e condomínio edilício, apresentar as concepções usuais da doutrina pela não personificação do condomínio edilício e apontar suas fragilidades, isto é, apontar em que momentos são vislumbradas brechas de argumentação ou, ao menos, a possibilidade de a mesma contingência ser abordada de forma diferente, desta vez, de maneira a não impedir a personificação.

A fim de perseguir esse objetivo, foram empregados o método crítico-reflexivo, para abordagem geral do trabalho, e a técnica de pesquisa documental, durante a fase de sua execução.

O presente artigo encontra-se estruturado em duas partes: a primeira é destinada à conceituação de pessoa jurídica e condomínio edilício, indispensável ao prosseguimento do trabalho e à compreensão do artigo como um todo; a segunda parte aborda o cerne do trabalho, as concepções doutrinárias usuais sobre impossibilidade de personificação do condomínio edilício e suas fragilidades. Ao evidenciar que tais construções não excluem a possibilidade de o condomínio edilício ser considerado pessoa jurídica, espera-se demonstrar que a doutrina dominante pode ser relativizada, não constituindo paradigma absoluto. 


\section{CONSTRUÇÕES TEÓRICAS INICIAIS}

Nesta seção são abordados os conceitos de dois institutos imprescindíveis à compreensão deste trabalho - a pessoa jurídica e o condomínio edilício -, além de suas características e contingências específicas.

\subsection{Pessoa jurídica - conceito, requisitos e características}

Para conceituar pessoa jurídica, primeiramente é necessário esclarecer qual o papel da personalidade nesse contexto. A personalidade da pessoa jurídica, conforme Tepedino, vai além de sua acepção subjetiva ${ }^{1}$. Apesar da relevância desse aspecto, a personalidade não se resume à plena capacidade para ser sujeito de direitos e deveres na ordem jurídica.

Personalidade não é mais sinônimo de subjetividade ${ }^{2}$, atributo que, apesar de essencial, não é exclusivo da pessoa jurídica. Existem entes que, dotados temporariamente de subjetividade, em especial no processo civil, não são considerados pessoas jurídicas - como a massa falida, o espólio e, embora aqui seja contestado, o condomínio edilício.

Por óbvio, não está se dizendo que a pessoa jurídica agora compartilha das peculiaridades da pessoa física no que concerne à proteção de atributos da personalidade que advêm da dignidade da pessoa humana, tal é inconcebível. Na realidade, o que se defende atualmente é que a personalidade da pessoa jurídica traduz-se no conjunto de suas características e de seu caráter duradouro.

Por isso, pela importância da presença de determinados elementos em conjunto para a configuração de pessoa jurídica, passar-se-á aos conceitos elaborados pela doutrina e à enunciação de características e requisitos de existência da pessoa jurídica.

Conforme Amaral, uma pessoa jurídica é “um conjunto unitário de pessoas ou de bens, organizado para a obtenção de fins comuns específicos, com individualidade e autonomia

\footnotetext{
1 TEPEDINO, Gustavo. "Notas sobre a Desconsideração da Personalidade Jurídica". In: TEPEDINO, Gustavo; FACHIN, Luiz Edson (orgs.). Diálogos sobre Direito Civil - volume II. Rio de Janeiro: Renovar, 2008, pp. 46.

${ }^{2}$ Tepedino trata a capacidade de direito como subjetividade, termo que prefere por destacar a condição de sujeito de direitos da pessoa física ou jurídica, distinguindo-a de personalidade, que a contém e, por isso, é mais abrangente.
} 
próprias"3 e suas características - indispensáveis à conformação de sua personalidade compõem-se dos seguintes elementos: a) capacidade de direito e de fato, própria; b) existência de uma estrutura organizativa artificial; c) objetivos comuns de seus membros; d) patrimônio próprio e independente do de seus membros e e) publicidade de sua constituição, isto é, o registro dos seus atos constitutivos nas repartições competentes ${ }^{4}$.

Venosa, por sua vez, trata a pessoa jurídica como "ente abstrato gerado pela vontade e necessidade do homem, surgindo como conjunto de pessoas ou bens com aptidão para adquirir direitos e contrair obrigações" ${ }^{5}$. Sua existência depende da observância aos requisitos de 1) vontade humana criadora; 2) observância das condições legais para sua formação e 3) finalidade lícita. Diz o autor que o primeiro item - vontade humana - é o ponto de nascimento da pessoa jurídica:

[...] o animus de constituir um corpo social diferente dos membros integrantes é fundamental. Existe uma pluralidade inicial de membros que, por sua vontade, se transforma numa unidade, na pessoa jurídica que futuramente passará a existir como ente autônomo. 0 momento em que passa a existir o vínculo de unidade caracteriza precisamente o momento da constituição da pessoa jurídica. ${ }^{6}$

Percebida a relevância do elemento volitivo, note-se que ele se configura a partir de um vínculo psíquico, não bastando a mera união física:

[...] não basta a simples aglomeração ou união de pessoas para que surja uma pessoa desvinculada da vontade e da autonomia de seus próprios membros. É imprescindível a vinculação psíquica entre os que constituem a pessoa jurídica para que esta assim seja considerada. É essa vinculação jurídica (...) que imprime unidade orgânica ao ente criado. ${ }^{7}$

Os conceitos, características e requisitos abordados são retomados quando do apontamento de fragilidades das concepções doutrinárias objeto deste artigo. Por ora, afiguramse suficientes para a elucidação de o que seja uma pessoa jurídica. Passa-se à apresentação da construção teórica adotada para condomínio edilício.

\footnotetext{
${ }^{3}$ AMARAL, Francisco. Direito Civil: Introdução. 7. ed. rev., atual e aum. Rio de Janeiro: Renovar, 2008, p. 318.

${ }^{4}$ Ibidem, p. 314.

${ }^{5}$ VENOSA, Sílvio de Salvo. Direito Civil - Parte Geral. 10. ed. São Paulo: Atlas, 2010. (Coleção Direito Civil; v. 1), p. 223.

${ }^{6}$ Ibidem, p. 227.

${ }^{7}$ Ibidem, p. 224.
} 


\subsection{Condomínio edilício - conceito e apontamentos iniciais sobre sua não consideração como pessoa jurídica no ordenamento brasileiro}

Em primeiro lugar, importa esclarecer que é utilizado neste artigo o termo "condomínio edilício" e não outros empregados de forma inconstante pela doutrina - como "condomínio relativo", “condomínio por andares ou apartamentos”, “propriedade horizontal” ou "condomínio horizontal" - por ser condomínio edilício a fórmula escolhida pelo legislador do Código Civil de 2002 (CC/02) para referir-se ao instituto.

De modo a conceituar o condomínio edilício, faz-se necessário revisitar o conceito de condomínio. A utilidade dessa revisão está no fato de que as particularidades do condomínio geral informam o que o condomínio edilício não é. Não à toa, diz Mezzari que pecou o legislador ao denominar condomínio edilício um instituto que tanto se distancia do condomínio em sua acepção geral ${ }^{8}$.

Pereira traça um paralelo eficiente entre os dois institutos ${ }^{9}$. Ensina que o condomínio dito clássico assenta seus fundamentos em três pontos. O primeiro deles é a situação de domínio da coisa inteira por uma pluralidade de sujeitos, sendo o poder jurídico de cada condômino exercido na projeção de sua quota ideal. O condomínio edilício é diferente no sentido de que não há poder jurídico dos condôminos, na medida de suas quotas ideais, sobre a coisa toda, apenas sobre a parte correspondente às áreas comuns; a parte restante - a unidade autônoma -, importa em exercício de poder que exclui todos os demais participantes da co-propriedade.

O segundo ponto fundamental do condomínio clássico é sua transitoriedade, "tanto em razão de sua própria natureza oposta à qualidade exclusiva da propriedade como porque milenarmente tem sido fonte permanente de constantes litígios” ${ }^{10}$. Opondo-se a esse caráter, o condomínio edilício, pela relação de dependência entre propriedade e co-propriedade a ele ínsita, traz em si a ideia de comunhão permanente. Finalmente, o terceiro ponto distintivo do condomínio geral é o fato de que

[...] nenhum condômino tem o direito de dar a terceiros a posse, o uso ou o gozo da propriedade sem o prévio consenso dos demais (...) nem pode alienar a sua

${ }^{8}$ MEZZARI, Mario Pazutti. Condomínio e Incorporação no Registro de Imóveis. Porto Alegre: Norton, 2002, p. 39.

9 PEREIRA, Caio Mário da Silva. Condomínio e Incorporações; edição atualizada segundo a legislação vigente. 10. ed. Rio de Janeiro: Forense, 1999, pp. 76-78.

10 Ibidem, p. 76. 
quota-parte a pessoa estranha ao condomínio, sem reconhecer a qualquer dos consócios preferência. ${ }^{11}$

O condomínio edilício, quanto a essa última disposição, não poderia ser mais diverso. Nele, o destino da unidade autônoma - e por complementação, também o da quota ideal das áreas comuns - fica ao livre arbítrio do condômino proprietário, sem necessidade de prévia audiência dos demais condôminos ou observação de sua preferência. Como no condomínio edilício o direito exclusivo sobre a unidade autônoma não se destaca do direito sobre as partes comuns, os demais condôminos se verão sujeitos à convivência com a pessoa que o proprietário original escolher para habitar o edifício, à sua revelia.

Realizadas essas distinções, e já com uma boa noção de o que seja o instituto trabalhado neste artigo, doravante o termo condomínio será utilizado para designar de forma mais breve o condomínio edilício, embora, pelo que foi visto, não se esteja remetendo ao condomínio geral, mas utilizando-se de sinônimo.

Adentrando finalmente em âmbito de conceituação, para a maioria esmagadora da doutrina - e aí se encontram Pereira, Rizzardo e Venosa -, o condomínio edilício trata-se de direito real novo, complexo, em que a propriedade exclusiva e a co-propriedade encontram-se em estado de dependência, verdadeira simbiose orgânica ${ }^{12}$. Sem a presença concomitante desses dois elementos, não existe condomínio edilício.

Oliva e, de certa forma, Mezzari, destoam ligeiramente desse grupo pois, embora reconheçam o condomínio como direito real, tratam-no também sob um ponto de vista subjetivo. Para Mezzari, o condomínio refere-se às relações existentes entre os diferentes proprietários das unidades autônomas e de suas relações condominiais sobre as coisas de uso comum $^{13}$. Oliva, por sua vez, considera o termo condomínio edilício um expediente técnico do legislador para designar a coletividade de condôminos ${ }^{14}$.

Neste artigo adota-se uma concepção mista de condomínio edilício, referindo-se tanto ao direito real em que coexistem propriedade exclusiva e co-propriedade, como também à coletividade de pessoas às quais corresponde tal direito real. Conforme essa conceituação, o

\footnotetext{
11 Ibidem, p. 77.

12 Ibidem, p. 93.

13 MEZZARI, Mario Pazutti. Condomínio e Incorporação no Registro de Imóveis. Porto Alegre: Norton, 2002, p.40.

14 OLIVA, Milena Donato. "Condomínio Edilício e Subjetividade". In: TEPEDINO, Gustavo; FACHIN, Luiz Edson (orgs.). Diálogos sobre Direito Civil - volume II. Rio de Janeiro: Renovar, 2008, p. 90.
} 
condomínio edilício é revestido de um aspecto objetivo - o direito real - e de um aspecto subjetivo - a coletividade de condôminos.

Em sentido semelhante, há a construção de Kollet, que critica a concepção unívoca da doutrina majoritária com relação ao condomínio edilício:

[...] se tratam de dois entes para enquadramento em dois seres: um de natureza real, que é composto pela realidade física do empreendimento - partes exclusiva e comuns; outro que é composto pelo complexo gerencial e administrativo que exsurge da necessidade de organizar as relações que uma parcela do ente físico as áreas comuns - impõe. 0 segundo, que decorre indissoluvelmente do primeiro, diz respeito à linguagem utilizada para identificação dos entes que são inatos às habitações coletivas. ${ }^{15}$

Estabelecido o conceito, passa-se ao fato de que o condomínio edilício não é considerado pessoa jurídica pelo ordenamento brasileiro. Depreende-se esse entendimento, a título exemplificativo, a partir do disposto no art. 12 do Código de Processo Civil - que ao tratar da representação em juízo, coloca o condomínio (inciso IX) como ente diverso da pessoa jurídica (inciso $\mathrm{VI}$ ).

A não personificação traz consequências desabonadoras ao condomínio e àqueles que dele fazem parte. Entre elas, está o fato de que a Lei No 6.015/73 - a Lei de Registros Públicos prevê a possibilidade de pessoa física ou pessoa jurídica registrar em seu nome bem imóvel (“art. $176, \$ 1^{\circ}$, II - são requisitos da matrícula: 4) o nome, domicílio e nacionalidade do proprietário, bem como: a) tratando-se de pessoa física (...); b) tratando-se de pessoa jurídica (...)"), mas nada fala sobre a possibilidade de registro em nome de entes considerados despersonalizados, como o condomínio edilício. Essa omissão legal faz com que os condomínios encontrem resistência por parte dos órgãos registrais em operações necessárias e relativamente simples, como a aquisição de terreno contíguo destinado ao aumento de vagas de garagem.

Nesse sentido, há doutrinadores, como Washington de Barros Monteiro, que arguem que a solução mais eficaz para essa problemática - e outras que escapam à incidência da Lei de Registros Públicos ${ }^{16}$ - é o reconhecimento do condomínio como pessoa jurídica ${ }^{17}$. Esse viés

15 KOLLET, Ricardo Guimarães. Propriedade horizontal e condomínio edilício: em busca de uma identidade jurídica. Disponível em: <http://www.portalibest.com.br/img_sis/download/d4b136445cdf addc623cac6e26294099.pdf>. Acesso em 4 dez. 2011, pp. 9-10.

${ }_{16}^{16} \mathrm{Um}$ exemplo é a possibilidade de credor de dívida com o condomínio atingir diretamente o patrimônio dos condôminos, na medida de suas quotas-partes. Se investido de personalidade, o condomínio edilício, ao dispor de patrimônio autônomo, protegeria - ao menos em um primeiro momento - os condôminos dessa situação. 
doutrinário - minoritário, mas interessante para os fins a que se propõe esse artigo -, ganha força pelo reconhecimento de personalidade jurídica ao condomínio edilício em ordenamentos estrangeiros, como o francês, o argentino e o chileno ${ }^{18}$. Ainda assim, não houve vigor suficiente para levar adiante projeto de lei sobre o assunto nas casas legislativas brasileiras ${ }^{19}$, tal é a supremacia das concepções usuais pela não personalização do condomínio edilício.

Levando-se em conta essa situação de não reconhecimento do condomínio edilício como pessoa jurídica e suas consequências, ademais da força impositiva do status quo doutrinário, passa-se à próxima seção do presente trabalho, em que se propõe apontar as fragilidades das concepções usuais da doutrina brasileira sobre o assunto, malgrado seu prestígio e vinculatividade atuais.

\section{FRAGILIDADES DAS CONCEPÇÕES DE NÃO CONSIDERAÇÃO DO CONDOMÍNIO EDILÍCIO COMO PESSOA JURÍDICA}

Nesta seção são apresentadas sínteses das concepções doutrinárias usuais de não personificação jurídica do condomínio edilício a fim de, em seguida, serem apontadas suas fragilidades ou seu caráter não absoluto. Não são abordados autores que em suas construções se limitaram a concordar com o sistema legal, sem justificá-lo, como Coelho ${ }^{20}$ e Mezzari ${ }^{21}$.

\subsection{Condomínio edilício como ente despersonalizado}

A primeira concepção, apoiada pela maior parte dos doutrinadores civilistas, é a do condomínio edilício como ente despersonalizado. Émbora sua subjetividade seja reconhecida em

\footnotetext{
${ }^{17}$ MONTEIRO, Washington de Barros. Curso de Direito Civil: Direito das Coisas. 37. ed. rev. e atual. por Carlos Alberto Dabus Maluf. São Paulo: Saraiva, 2003, p. 224.

${ }^{18}$ BRASIL. Projeto de Lei 4816/2009. Acrescenta dispositivo à Lei $N^{0} 6.015$, de 31 de dezembro de 1973, que dispõe sobre Registros Públicos e à Lei $\mathrm{N}^{0} 10.406$, de 10 de janeiro de 2002, que instituiu o Código Civil, conferindo aos condomínios edilícios a oportunidade de se constituírem como pessoas jurídicas. Disponível em: <http://www.camara.gov.br/proposicoesWeb/fichadetramitacao?idProposicao=426013>. Acesso em 4 dez. 2011.

${ }^{19}$ O Projeto de Lei 4816/2009, que conferiria aos condomínios edilícios a oportunidade de se constituírem como pessoas jurídicas, foi arquivado no final de 2010, por conta do fim da legislatura.

${ }^{20}$ COELHO, José Fernando Lutz. Condomínio Edilício: Teoria e Prática. Porto Alegre: Livraria do Advogado Ed., 2006, p. 23.

${ }^{21}$ MEZZARI, Mario Pazutti. Condomínio e Incorporação no Registro de Imóveis. Porto Alegre: Norton, 2002, p. 38.
} 
situações determinadas, como durante o processo civil, tal subjetividade não pode ser equiparada à personalidade, pela temporariedade da primeira e pela falta de elementos componentes da segunda, em especial o elemento volitivo (v. supra). Venosa, ao referir-se a entes dessa natureza - que chama de entes de personificação anômala -, descreve-os como:

[...] determinadas entidades com muitas das características das pessoas jurídicas, mas que não chegam a ganhar sua personalidade. Faltam-lhes requisitos imprescindíveis à personificação, embora, na maioria das vezes, tenham representação processual, isto é, podem agir no processo, ativa e passivamente, como ser transeunte entre a pessoa jurídica e um corpo apenas materializado, um simples agrupamento, sem que haja a affectio societatis, porque são formados independentemente da vontade de seus membros ou por ato jurídico que vincule um corpo de bens. ${ }^{22}$

Como percebido, o principal argumento dessa concepção pela não personificação do condomínio edilício é a ausência de vontade dos integrantes na formação e durante a existência do condomínio. O raciocínio é simples. A vontade humana criadora é requisito de existência da pessoa jurídica. Sem sua presença no ato de formação do ente, não há pessoa jurídica. Se, formado o ente, durante a sua existência esteja ausente a vinculação psíquica de seus membros rumo a um fim comum - vinculação esta denominada affectio societatis -, descaracteriza-se a pessoa jurídica como expressão de sua personalidade. Em suma, sem vontade, não há personificação.

Mas como é embasada a ausência de vontade na formação e existência do condomínio? Defende-se que o vínculo jurídico que une os condôminos não é pessoal - expressão de suas vontades - mas simplesmente real - previsão legal e contingência física. É o que diz, entre tantos, Pereira: “[no condomínio edilício], os proprietários não são associados. A reunião dos condôminos é destituída de personalidade. Falta completamente a affectio societatis. E se um vínculo jurídico os congrega, não é, certamente pessoal, mas real (...)."23.

A fragilidade desse argumento está na concepção unívoca de condomínio edilício adotada por esses doutrinadores. Tratando o condomínio em sua acepção objetiva, de direito real, de fato, a única vontade manifestada é a do proprietário quando da aquisição do bem. Mas se faz necessário recordar que o condomínio não é mera união de direitos reais, é uma coletividade de

\footnotetext{
${ }^{22}$ VENOSA, Sílvio de Salvo. Direito Civil - Parte Geral. 10. ed. São Paulo: Atlas, 2010. (Coleção Direito Civil; v. 1), p. 239.

${ }_{23}$ PEREIRA, Caio Mário da Silva. Condomínio e Incorporações; edição atualizada segundo a legislação vigente. 10. ed. Rio de Janeiro: Forense, 1999, p. 81.
} 
condôminos, verdadeiro complexo relacional. A partir dessa acepção subjetiva, ao contrário do que propõe a doutrina tradicional, é possível vislumbrar que a vontade dos condôminos dirige ou pelo menos pode dirigir - a formação e existência do condomínio como ente autônomo.

Como esclarece Kollet, o elemento volitivo está presente em todas as etapas de formação do condomínio ${ }^{24}$. É com um ato de vontade que determinada pessoa ou coletividade institui o regime de propriedade horizontal sobre certa área física (art. 1.332, CC/02). Ainda, e com maior relevância, é a partir de uma exteriorização coletiva de vontades que é elaborada a convenção de condomínio, instrumento constitutivo do condomínio edilício (art. 1.333, CC/02). Se, ao acordarem sobre seus direitos, deveres, objetivos, representantes e fiscalizadores, os condôminos operam a constituição de novo ente - e isso é reconhecido pela lei -, como supor que aí não há vontade humana criadora? Há manifestação e equalização de vontades. Há vinculação psíquica dos condôminos no tocante aos seus interesses comuns.

Essa convergência de vontades se mantém mesmo após a formação do condomínio, durante o período de sua existência, por encontrar-se vinculada ao disposto na convenção. Isso não quer dizer que os objetivos perseguidos sejam estanques. A equalização de vontades operada periodicamente nas assembleias condominiais propicia a renovação do liame psíquico entre os condôminos, que decidem manter sua vinculação aos mesmos interesses comuns ou dirigir-se a outros. Embora possam variar, importa destacar que os interesses da coletividade de condôminos têm uma diretriz constante: o bem estar de todos e de cada um dos condôminos.

Engana-se Rizzardo ao dizer que "inexiste laço social ou vínculo entre os condôminos para uma atividade comum" 25 , referindo-se à affectio societatis. Ela está presente na vontade de colaboração ativa dos condôminos ${ }^{26}$, em seu compromisso de contribuir para uma convivência saudável e pacífica em condomínio, coadunante com o bem estar dos moradores, fim último do condomínio edilício.

Frente a essas considerações, parece absurda a declaração de Venosa de que "quem adquire um apartamento não está buscando algum relacionamento com os co-proprietários. Esse

\footnotetext{
24 KOLLET, Ricardo Guimarães. Propriedade horizontal e condomínio edilício: em busca de uma identidade jurídica. Disponível em: <http://www.portalibest.com.br/img_sis/download/d4b136445cdfa ddc623cac6e26294099.pdf>. Acesso em 4 dez. 2011, pp. 25-28.

25 RIZZARDO, Arnaldo. Direito das Coisas: Lei $n^{\circ}$ 10.406, de 10.01.2002. 4. ed. rev. e atual. Rio de Janeiro: Forense, 2009, p. 243.

26 KOLLET, Ricardo Guimarães. Propriedade horizontal e condomínio edilício: em busca de uma identidade jurídica. Disponível em: <http://www.portalibest.com.br/img_sis/download/d4b136445cdfa ddc623cac6e26294099.pdf>. Acesso em 4 dez. 2011, p. 29.
} 
relacionamento decorre de situação fática e não de uma situação jurídica." ${ }^{27}$. A convenção de condomínio, uma vez registrada (art. 1.333, parágrafo único, CC/02), torna-se oponível a terceiros. Como tal oponibilidade resulta em presunção de conhecimento geral, tendo sido adquirida unidade condominial, presume-se que o adquirente leu a convenção e aceita seus termos, passando no mesmo instante a compartilhar dos interesses acordados pelos demais condôminos, a relacionar-se. Por isso, pode-se dizer que quem adquire unidade imobiliária, embora possa não buscá-lo, está inevitavelmente relacionando-se, e não apenas em decorrência dos fatos (a proximidade física, e.g.), mas também por conta de sua vinculação imediata ao disposto em convenção de condomínio, ato inegavelmente jurídico.

Expostas as fragilidades do argumento que nega personificação ao condomínio edilício pela ausência do elemento volitivo em sua formação e existência, passa-se à análise de outro argumento da mesma concepção: a não personificação do condomínio pelo fato de "o domínio do imóvel não pertence[r] a uma pessoa jurídica" ${ }^{28}$. Pereira, defensor dessa óptica, alega que “[é] inadequada a invocação do conceito de personificação. (...) é indispensável a que o proprietário permaneça proprietário, e se não torne mero titular de uma quota ou parte social, e para que seu direito conserve a qualidade imobiliária, e não seja um bem móvel corpóreo."29.

A fragilidade desse argumento está em um aparente esquecimento de como funciona o regime patrimonial das pessoas jurídicas. Se o condomínio fosse reconhecido pelo ordenamento como pessoa jurídica, consoante ensina a doutrina mais vetusta, seu patrimônio não se confundiria com o de seus integrantes. É o que se chama princípio da autonomia patrimonial da pessoa jurídica. Se a unidade condominial integra o patrimônio de determinado condômino, por óbvio que esse bem pertence apenas a ele, e não ao condomínio. O condomínio, tomado hipoteticamente como pessoa jurídica, possuiria patrimônio próprio.

Entretanto, talvez se pergunte: qual patrimônio? Oriundo de qual fonte? As respostas poderiam ser várias, mas uma hipótese razoável é a de que esse patrimônio seria formado a partir do fundo de reserva do condomínio, mensalmente alimentado pelos condôminos através do pagamento das conhecidas taxas condominiais.

\footnotetext{
${ }^{27}$ VENOSA, Sílvio de Salvo. Direito Civil - Parte Geral. 10. ed. São Paulo: Atlas, 2010. (Coleção Direito Civil; v. 1), p. 243.

${ }_{28}$ PEREIRA, Caio Mário da Silva. Condomínio e Incorporações; edição atualizada segundo a legislação vigente. 10. ed. Rio de Janeiro: Forense, 1999, p. 81.

29 Ibidem, p. 89.
} 
Apontadas as fragilidades da concepção do condomínio edilício como ente despersonalizado, passa-se ao exame da segunda concepção: o condomínio edilício como expediente técnico a indicar a coletividade de condôminos.

\subsection{Condomínio como expediente técnico a indicar a coletividade de condôminos}

A segunda concepção, representada pelas construções de Oliva, é a do condomínio como expediente técnico a indicar a coletividade de condôminos. Tenta-se refutar a concepção do condomínio edilício como ente despersonalizado, mas por um viés que se distancia da ideia de personificação do instituto. Para Oliva:

O condomínio edilício consiste em direito real caracterizado pela coexistência da propriedade coletiva com a propriedade individual, e não um ente desprovido de subjetividade, para cuja viabilização o legislador criou expedientes técnicos que o protegessem das modificações particulares dos condôminos que, de resto, são muitas e aleatórias. ${ }^{30}$

Descartando até mesmo a hipótese de subjetividade, Oliva toma o instituto jurídico condomínio edilício como direito real. Até aí, nada de novo. Sua inovação está em considerar o termo jurídico condomínio edilício como designativo de uma coletividade a ser representada pelo síndico. Posto que o corpo de condôminos está sempre sujeito a mudanças, esse termo, indicativo de um conjunto determinável mas não determinado de condôminos, busca facilitar os atos praticados por essa coletividade e, consequentemente, por seu representante. Graças a ele, não há a necessidade de individualizar o grupo a cada ato - e com isso tornar mais lento o processo ou a negociação - mas só quando necessário. Não se trata de reconhecimento da subjetividade do condomínio edilício, mas sim de elemento que confere maior praticidade à coletividade e ao seu contexto. Nas palavras de Oliva:

(...) cuida-se (...) de expediente técnico que vincula - diretamente - uma coletividade que se altera livre, constante e aleatoriamente, de tal sorte que o legislador criou mecanismos para que essa instabilidade não interferisse na regular administração do condomínio. ${ }^{31}$

30 OLIVA, Milena Donato. "Condomínio Edilício e Subjetividade". In: TEPEDINO, Gustavo; FACHIN, Luiz Edson (orgs.). Diálogos sobre Direito Civil - volume II. Rio de Janeiro: Renovar, 2008, p. 97.

${ }^{31}$ Ibidem, p. 91. 
Oliva explica que, mesmo sendo efetuadas operações de compra e venda em nome do condomínio ou constando ele como parte em processos, o condomínio edilício não é ente provido de subjetividade, quiçá de personalidade, mas simples direito real. Em sua concepção, quem realiza negócio jurídico ou é parte em processos são os próprios condôminos, representados pelo síndico, entendimento semelhante ao de Coelho ${ }^{32}$. Completa:

O objetivo [...] de se colocar o "condomínio" como parte nas contratações não é derrogar a norma de que só quem tem personalidade jurídica (...) pode contrair direitos e obrigações, mas possibilitar a formação de uma relação jurídica diretamente com a coletividade mutante dos condôminos. ${ }^{33}$

Ainda, Oliva adiciona que o condomínio prescinde de subjetividade pois a representação do síndico é mecanismo suficiente para sua boa administração ${ }^{34}$. Essa representação tem caráter sui generis, diferenciando-se da representação legal e da representação voluntária. É legal no sentido de encontrar-se prevista em lei, mas não representa pessoa perfeitamente individualizada - como na representação legal de incapazes, por exemplo. É voluntária no sentido de que os condôminos decidem por maioria em assembleia quem irá representá-los, ademais de os atos do síndico vincularem diretamente todos os condôminos - mesmo os discordantes -, mas o síndico não é investido unilateralmente dessa função por pessoa determinada, e tampouco busca satisfazer os interesses de cada representado individualmente, como ocorre na representação voluntária. Em resumo, por conta dessas características presumese a eficiência e suficiência da representação do síndico na resolução de problemas relativos ao condomínio.

Essa concepção é frágil no sentido de que a representação do síndico não soluciona os entraves citados acima, ocasionados pela falta de personalidade jurídica do condomínio. A menos que, lado a lado com a adoção da concepção de Oliva, ocorra uma reconciliação dos órgãos registrais com a finalidade da lei - e não com sua letra -, em prol do bem comum, como fala Maluf ${ }^{35}$, é difícil imaginar que seja concedido o registro de determinado bem em nome do condomínio - na acepção de designativo de coletividade de condôminos, não pessoa jurídica.

\footnotetext{
${ }^{32}$ COELHO, José Fernando Lutz. Condomínio Edilício: Teoria e Prática. Porto Alegre: Livraria do Advogado Ed., 2006, p. 23.

33 OLIVA, Milena Donato. "Condomínio Edilício e Subjetividade". In: TEPEDINO, Gustavo; FACHIN, Luiz Edson (orgs.). Diálogos sobre Direito Civil - volume II. Rio de Janeiro: Renovar, 2008, p. 91.

${ }^{34}$ Ibidem, p. 83.

${ }^{35}$ MALUF, Carlos Alberto Dabus; MARQUES, Márcio Antero Motta Ramos. 0 condomínio edilício no novo Código Civil. 2. ed. rev. e atual. São Paulo: Saraiva, 2005, pp. 13-17.
} 
Ainda, a própria Oliva aponta uma consequência da aplicação de sua concepção que seria bastante desvantajosa aos condôminos: seus patrimônios pessoais poderiam ser diretamente atingidos, na medida de suas quotas-partes, para o pagamento de dívidas contraídas em benefício comum ${ }^{36}$. A personificação do condomínio edilício, por seu lado, poderia resolver ou, no limite, amenizar essa situação. Tendo em vista que o patrimônio da pessoa jurídica é autônomo com relação ao de seus integrantes, as reservas do condomínio seriam alcançadas pelo credor em primeiro lugar, restando protegidos - ao menos em um primeiro momento - os patrimônios dos condôminos.

Por último, se ajustada de forma a conceber o condomínio edilício, como instituto, sob uma óptica subjetiva - no sentido de que o condomínio não é expediente de designação da coletividade, mas é a própria coletividade, em seu complexo de relações e interesses -, a concepção de Oliva poderia contribuir significativamente para a doutrina de personificação do condomínio edilício.

Haveria ensejo para redefinição do papel do síndico no condomínio personificado: a ele caberia não mais representar, mas presentar ${ }^{37}$, no sentido de prover voz à pessoa jurídica, não de falar por ela. Isso não quer dizer que o síndico teria poder de decisão absoluto - prescindindo das declarações de vontade dos condôminos. Pelo contrário: o síndico vincularia sua conduta a tudo que fosse estabelecido no órgão deliberativo do condomínio, a assembleia.

Embora diga Venosa que a vontade do ente abstrato é diversa da vontade de seus membros $^{38}$, isso diz respeito à vontade dos membros individualmente considerados, não à vontade deliberada por seus membros coletivamente. A pessoa jurídica, ressalte-se, não é um ente pensante, totalmente independente, pois seus rumos dependem do pensamento daqueles que dela fazem parte. Tem-se que, com a personificação do condomínio edilício, os condôminos não perdem sua relevância, pelo contrário: veem seus interesses potencializados pela atuação de um ente cujo alcance trancende seus esforços individuais.

Feitos os apontamentos sobre a concepção do condomínio edilício como expediente técnico a indicar a coletividade de condôminos, passa-se às considerações finais do presente trabalho.

\footnotetext{
36 OLIVA, Milena Donato. "Condomínio Edilício e Subjetividade". In: TEPEDINO, Gustavo; FACHIN, Luiz Edson (orgs.). Diálogos sobre Direito Civil - volume II. Rio de Janeiro: Renovar, 2008, p. 93.

${ }^{37}$ VENOSA, Sílvio de Salvo. Direito Civil - Parte Geral. 10. ed. São Paulo: Atlas, 2010. (Coleção Direito Civil; v. 1), p. 235.

38 Ibidem, p. 225.
} 


\section{CONCLUSÃO}

Este artigo buscou responder à pergunta "por que o condomínio edilício não pode ser pessoa jurídica?". Tendo sido analisadas as concepções usuais da doutrina para a não personificação do condomínio e apontadas suas fragilidades, chegou-se à resposta de que, na verdade, o condomínio edilício pode ser pessoa jurídica, bastando que para isso seja superada a concepção unívoca com relação ao instituto.

A fragilidade - ou antes o erro - das contruções examinadas está no fato de tomarem o condomínio edilício pura e simplesmente como direito real e, por conta dessa classificação e toda a carga que a acompanha (carga que remonta à propriedade e ao individualismo ínsito a ela), deixarem de lado o aspecto subjetivo envolvido.

Esquecem que o condomínio edilício é também a coletividade de condôminos, coletividade que, como foi demonstrado, constitui o condomínio e dirige-o conforme as múltiplas vontades de seus integrantes são vinculadas a interesses comuns, cujo fim último é o bem estar de todos e de cada um dos condôminos. Tal bem estar se desdobra em várias ações às quais o condomínio tem a prática obstada por conta de seu não reconhecimento como pessoa jurídica. O que lhe falta? As concepções usuais da doutrina, seja a que o considera ente despersonalizado ou a que o trata expediente técnico, não são capazes de tolher completamente a possibilidade de personificação.

Quando entra em cena a acepção subjetiva do condomínio, a coletividade revestida de vontade, os paradigmas antes absolutos, seguros em sua acepção real, desestabilizam-se, relativizam-se. Considerando que o reconhecimento da personificação do condomínio edilício facilitaria sobremaneira a administração condominial e as operações envolvidas nesse contexto, tem-se que essa é uma questão à qual nossos doutrinadores não podem se acomodar, eximir-se. 0 presente artigo se propõe como um dos primeiros passos na renovação dessa discussão.

\section{REFERÊNCIAS}

AMARAL, Francisco. Direito Civil: Introdução. 7. ed. rev., atual e aum. Rio de Janeiro: Renovar, 2008. 
BRASIL. Projeto de Lei 4816/2009. Acrescenta dispositivo à Lei $\mathrm{N}^{0} 6.015$, de 31 de dezembro de 1973, que dispõe sobre Registros Públicos e à Lei № 10.406, de 10 de janeiro de 2002, que instituiu o Código Civil, conferindo aos condomínios edilícios a oportunidade de se constituírem como pessoas jurídicas. Disponível em: <http://www.camara.gov.br/proposicoesWeb/ fichadetramitacao?idProposicao=426013>. Acesso em 4 dez. 2011.

COELHO, José Fernando Lutz. Condomínio Edilício: Teoria e Prática. Porto Alegre: Livraria do Advogado Ed., 2006.

KOLLET, Ricardo Guimarães. Propriedade horizontal e condomínio edilício: em busca de uma identidade jurídica. Disponível em: <http://www.portalibest.com.br/img_sis/download/d4b1 36445cdfaddc623cac6e26294099.pdf>. Acesso em 4 dez. 2011.

MALUF, Carlos Alberto Dabus; MARQUES, Márcio Antero Motta Ramos. O condomínio edilício no novo Código Civil. 2. ed. rev. e atual. São Paulo: Saraiva, 2005.

MEZZARI, Mario Pazutti. Condomínio e Incorporação no Registro de Imóveis. Porto Alegre: Norton, 2002.

MONTEIRO, Washington de Barros. Curso de Direito Civil: Direito das Coisas. 37. ed. rev. e atual. por Carlos Alberto Dabus Maluf. São Paulo: Saraiva, 2003.

OLIVA, Milena Donato. "Condomínio Edilício e Subjetividade". In: TEPEDINO, Gustavo; FACHIN, Luiz Edson (orgs.). Diálogos sobre Direito Civil - volume II. Rio de Janeiro: Renovar, 2008.

PEREIRA, Caio Mário da Silva. Condomínio e Incorporações; edição atualizada segundo a legislação vigente. 10. ed. Rio de Janeiro: Forense, 1999.

RIZZARDO, Arnaldo. Direito das Coisas: Lei $n^{\circ} 10.406$, de 10.01.2002. 4. ed. rev. e atual. Rio de Janeiro: Forense, 2009.

TEPEDINO, Gustavo. "Notas sobre a Desconsideração da Personalidade Jurídica". In: TEPEDINO, Gustavo; FACHIN, Luiz Edson (orgs.). Diálogos sobre Direito Civil - volume II. Rio de Janeiro: Renovar, 2008.

VENOSA, Sílvio de Salvo. Direito Civil - Parte Geral. 10. ed. São Paulo: Atlas, 2010. (Coleção Direito Civil; v. 1)

Recebido em: 29.09.2013

Aprovado em: 19.11.2013 